\title{
Acute Reversible Ischemic Stroke after Snake Bite
}

\author{
Alok Kumar Sahoo, Bhavna Sriramka ${ }^{1}$ \\ Department of Anesthesia and Critical Care, All India Institute of Medical Sciences, ${ }^{1}$ Department of Anesthesia and Critical Care, IMS and SUM Hospital, \\ Bhubaneswar, Odisha, India
}

\section{Abstract}

Snake bite is very common in India. Ischemic stroke after snake bite has been described in the literature sparsely. Furthermore, the onset of stroke and its clinical reversibility is a rarity. Here, we present a case of snake bite with ischemic stroke which has clinically reversible outcome.

Keywords: Snake bite, hemiplegia, ischemic stroke, reversible

\section{INTRODUCTION}

Snake bite and related deaths are very common in India. According to the most conservative estimate, 45,900 annual snakebite deaths occur in India. ${ }^{[1,2]}$ The snake venoms are basically two types: neurotoxic and hemotoxic. The neurotoxic venom degrades neurotransmitters and depolarizes the axonal membrane, and thus inhibits the conduction of nerve impulses. Hemotoxic venom causes tissue destruction and also produces its effect through circulatory system..$^{[1]}$

The Indian krait's venom consists mostly of powerful neurotoxins which induce muscle paralysis. Viperid venom usually contains protein-degrading protease enzymes that cause symptoms such as pain, local swelling, erythema and necrosis, and disruption of the blood clotting system. ${ }^{[3]}$

\section{Case Report}

A 36-year-old male was admitted to the Intensive Care Unit (ICU) of a tertiary care hospital with complaint of snake bite while working in the agricultural field. On admission, the patient was conscious and oriented and had tachycardia. No neurological sign was evident during examination. The patient had no comorbid illness and was a nonsmoker, nonalcoholic, and nonhypertensive. On local examination, there were mild erythema and swelling at the site of bite; fang marks were not clearly visible because of local application of herbal paste [Figure 1]. Clot retraction test was found negative. He was immediately treated with $100 \mathrm{ml}$ (10 vials) loading dose

\begin{tabular}{|l|l|}
\hline \multicolumn{3}{c|}{ Access this article online } \\
\hline Quick Response Code: & Website: \\
& www.ijccm.org \\
\hline
\end{tabular}

of equine polyvalent antisnake venom (ASV-ASIA, Bharat Serum, Ambernath (E), Maharastra, India) after a test dose, followed by continuous intravenous administration of $50 \mathrm{ml}$ every $6 \mathrm{~h}$ by infusion. ASV was discontinued once $20 \mathrm{~min}$ whole blood clotting time showed clot formation.

Biochemical profiles suggested leukocytosis, bleeding time (6.5 min), abnormal prothrombin time (25 s), international normalized ratio 1.35 , serum fibrinogen level $185 \mathrm{mg} / \mathrm{dl}$, and an elevated activated plasma thromboplastin time (58 s; control $36 \mathrm{~s}$ ). Liver function and renal function were normal. On the $2^{\text {nd }}$ day (approximately after $18 \mathrm{~h}$ after the snake bite), the patient developed right-sided paresis, aphasia, and became drowsy with Glasgow Coma Scale score of 6 . The patient was intubated and ventilated initially with pressure support. Computed tomography (CT) brain showed acute ischemic infarct in the left middle cerebral artery territory with edema [Figure 2]. Doppler study suggested no evidence of arterial or venous thrombosis. Furthermore, echocardiographic and electrocardiographic findings were unremarkable.

The patient showed gradual improvement with conservative management and was extubated on day 5. Muscle power gradually improved and the patient started walking with support on day $14^{\text {th }}$ of the ICU admission. We obtained detailed informed consent from the patient for publication.

Address for correspondence: Dr. Bhavna Sriramka, Department of Anesthesia, and Critical Care, IMS and SUM Hospital, Bhubaneswar, Odisha, India. E-mail: bhavna.sriramka@gmail.com

This is an open access journal, and articles are distributed under the terms of the Creative Commons Attribution-NonCommercial-ShareAlike 4.0 License, which allows others to remix, tweak, and build upon the work non-commercially, as long as appropriate credit is given and the new creations are licensed under the identical terms.

For reprints contact: reprints@medknow.com

How to cite this article: Sahoo AK, Sriramka B. Acute reversible ischemic stroke after snake bite. Indian J Crit Care Med 2018;22:611-2. 


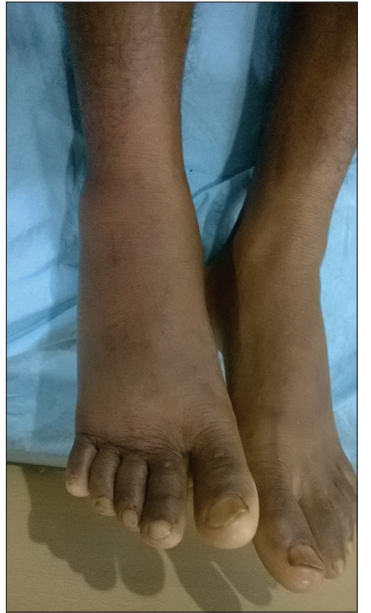

Figure 1: Minimal tissue reaction at the site of bite in the right lower dorsum of the foot

\section{Discussion}

Ischemic stroke, following snake bite, is rare. Very few cases of ischemic stroke resulting from a viper bite have been reported. Bashir and Jinkins reported a patient with hemiplegia and aphasia, consistent with a middle cerebral artery infarction after Russell's viper bite. ${ }^{[4]}$ In an observational study of 309 cases of snake bite, Mosquera et al. reported cerebrovascular complications in eight patients (seven hemorrhagic strokes and one ischemic stroke). ${ }^{[5]}$ Narang et al. reported a case of ischemic cerebral infract following viper bite. ${ }^{[6]}$

The viper venom has both anticoagulant and procoagulant effects; the procoagulation and platelet-aggregating properties are due to the presence of cerastobin, factor IVa, cerastocytin, cerastotin, and afaacytin. ${ }^{[7-9]}$ These various protein products have thrombin-like enzyme activity; different toxins activate different parts of the coagulation cascade, resulting in the formation of fibrin in the blood stream that leads to small and even large vessel occlusions due to the micro-thrombi which in turn will result in cerebral infarction, or toxin which may cause severe vasospasm. Toxic vasculitis may also lead to infraction. ${ }^{[10]}$

The patient was young and with no risk factors for stroke. His clinical presentations and radiological findings strongly suggest a vascular occlusion as a cause for their deficit. It could have resulted from the procoagulant and platelet-aggregating effects of toxin or toxin-induced vasculitis or toxin-induced vascular spasm and accompanying endothelial damage. We could not ascertain the subtype of snake, but the clinical features were suggestive of hemotoxic poisoning. However, the local reaction was minimal, and this finding further prevents us from correctly assign this symptomatology to a particular type of snake.

Acute demyelinating encephalomyelitis (ADEM) due to polyvalent ASV has been infrequently reported in literature. ${ }^{[1]}$ Therefore, our patient could have developed ADEM. However, ADEM usually presents late as patchy muscle paralysis which was not seen in our case. We did not do magnetic resonance imaging as the patient was recovering fast.

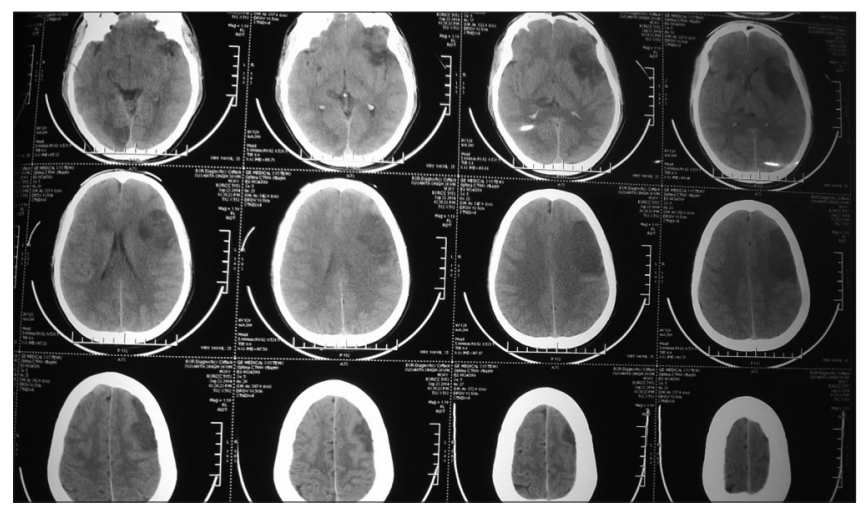

Figure 2: Computed tomography scan showing hypodense zone in the left middle cerebral artery territory with clear demarcation from normal tissue

\section{Declaration of patient consent}

The authors certify that they have obtained all appropriate patient consent forms. In the form, the patient has given his consent for his images and other clinical information to be reported in the journal. The patient understand that his name and initials will not be published and due efforts will be made to conceal identity, but anonymity cannot be guaranteed.

\section{Financial support and sponsorship}

Nil.

\section{Conflicts of interest}

There are no conflicts of interest.

\section{RefERENCES}

1. WHO/SEARO guidelines for the clinical management of snake bites in the Southeast Asian region. Southeast Asian J Trop Med Public Health 1999;30 Suppl 1:1-85.

2. Mohapatra B, Warrell DA, Suraweera W, Bhatia P, Dhingra N, Jotkar RM, et al. Snakebite mortality in India: A nationally representative mortality survey. PLoS Neg1 Trop Dis 2011;5.doi:10.1371/journal.pntd.0001018.

3. Marsh NA. Snake venoms affecting the haemostatic mechanism - A consideration of their mechanisms, practical applications and biological significance. Blood Coagul Fibrinolysis 1994;5:399-410.

4. Bashir R, Jinkins J. Cerebral infarction in a young female following snake bite. Stroke 1985;16:328-30.

5. Mosquera A, Idrovo LA, Tafur A, Del Brutto OH. Stroke following Bothrops spp. Snakebite. Neurology 2003;60:1577-80.

6. Narang SK, Paleti S, Azeez Asad MA, Samina T. Acute ischemic infarct in the middle cerebral artery territory following a Russell's viper bite. Neurol India 2009;57:479-80.

7. Farid TM, Tu AT, el-Asmar MF. Characterization of cerastobin, a thrombin-like enzyme from the venom of Cerastes vipera (Sahara sand viper). Biochemistry 1989;28:371-7.

8. Basheer AR, el-Asmar MF, Soslau G. Characterization of a potent platelet aggregation inducer from Cerastes cerastes (Egyptian sand viper) venom. Biochim Biophys Acta 1995;1250:97-109.

9. Dekhil H, Wisner A, Marrakchi N, El Ayeb M, Bon C, Karoui H, et al. Molecular cloning and expression of a functional snake venom serine proteinase, with platelet aggregating activity, from the Cerastes cerastes viper. Biochemistry 2003;42:10609-18.

10. Murthy JM, Kishore LT, Naidu KS. Cerebral infarction after envenomation by viper. J Comput Assist Tomogr 1997;21:35-7.

11. Tripathy S, Routray PK, Mohapatra AK, Mohapatra M, Dash SC. Acute demyelinating encephalomyelitis after anti-venom therapy in Russell's viper bite. J Med Toxicol 2010;6:318-21. 